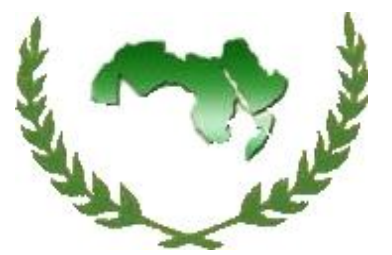

Arab Univ.

J. Agric. Sci.,

Ain Shams Univ.,

Cairo, 15(1), 157-166, 2007

\title{
COMPARATIVE STUDY OF SOME WEED CONTROL TREATMENTS ON DIFFERENT WEEDS GROWN IN ANNA APPLE ORCHARDS
}

\author{
El-Metwally', I.M. and Omaima, M. Hafez ${ }^{2}$ \\ 1. Botany Department, National Research Center, Dokki Giza Egypt \\ 2. Pomology Research Department, National Research Center, Dokki, Giza, Egypt
}

Keywords: weed control, Anna Apple, Mulching, Rice straw, Polyethylene sheet, Hand hoeing

\begin{abstract}
This study was carried out during two successive seasons 2005 and 2006 on Anna apple trees budded on Balady apple rootstock, grown in sandy soil at $(4 \times 4 \mathrm{~m})$ apart under drip irrigation system, in a private farm at El-Khatatba, Monofia Governorate. A comparative study of some weed control treatments have been studied on Anna apple trees with its associated weeds. The tested weed control methods were using different colours of polyethylene for mulching (green, blue, red, black and transparent), rice straw mulch, hand hoeing twice and two herbicides (Glyfosinate and Glyphosate) comparing with unweeded (control). All weed control treatments revented a significant reduction in fresh and dry weight of annual broad-leaved weeds, annual grasses, perennial and total weeds as compared with un weeded. The most effective treatments in decreasing fresh and dry weight of annual broad-leaves weeds were rice straw mulching, followed by black polyethylene mulch and Glyfosinate. While, rice straw, black polyethylene and Glyphosate treatments were the most effective in decreasing fresh and dry weight of grass and total weeds. Also, the highest decrement in fresh and dry weight of perennial weeds were obtained by rice straw mulching and Glyphosate treatments. Moreover, results showed a remarkable improvement in growth, nutritional status of apple trees and yield (kg/tree). Also, physical and chemical properties of the fruits were improved. The most pronounced treatment developed under such study on the growth reduction of different grown weeds,
\end{abstract}

meanwhile increased the apple tree growth, fruit yield associated with higher fruit quality was in rice straw mulching, black polyethylene mulching, Glyphosate treatments followed by hand hoeing twice treatment.

Finally, it could be concluded that soil mulching with rice straw can be used as a method for weed control in apple orchards. This method developed such advantages over herbicides, polyethylene mulch and hand hoeing in this concern. The possibility of using rice straw mulch for their many positive effects such as low coasts, in harmony with ecosystem without no harmful residual effect especially for exported fruits and for producing safe fruits for human nutrition. In additions, soil mulch with rice straw improving growth, leaves mineral contents as well as produced higher yield and better quality of apple fruits.

\section{INTRODUCTION}

Apple is one of the most important fruit in the world. Anna apple is one of the introduced horticultural crops in Egypt, cultivated in different soil types and irrigation systems. Commercial production of apple in Egypt, has been developed since the early introduction of low chilling cultivars. So, Anna apple proved the most dominant cultivar up till now (Stino et al 1985).

Weed control is one of the important factors which control the successful growth and productivity of apple orchards. Egyptian climate offers a very conductive environment for continuous growth of weeds. Frequent irrigation and nutrient applications, further enhance the weed problem, in fruit orchards. Weed utilize a major portion of 
nutrients and water which could be utilized by trees, resulting in poor tree growth and reduce yields. Also, weed harbor insects and disease organisms and reduce the efficiency of cultural and harvesting operations (Sabbah et al 1994). Since hand hoeing is laborious and expensive, so, different weed control methods were continuously evaluated in fruit orchards such as herbicides (El-

Shamma and Hassan 2001 and Banaszkiewicz and Kopytowski 2003) and/or covering soil with several mulching materials (Sinbel et al 1997 and Pedersen 1999).

Soil mulch (covering the soil by organic or synthetic materials) was recorded as a safe method to control weeds in comparison to herbicides application (Hussein and Radwan 2002). Organic mulches include straw and residues from rice, wheat crops like banana and sugar cane. Synthetic mulches include polyethylene (plastic), polypropylene sheets or film. Mulch system suppress weeds through their physical presence with soil surface (by shading, lowering soil-surface temperature, allelopathic activity and black the light stimules required for germination of many smallseeded weed species (Radwan and Hussein 2001). Mulching is very effective against annual weeds and some perennial weeds such as Cynodon dactylon and Convolvulus arvensis in apple orchard (Bhutani et al 1994; Hartley and Rahman 1997 and Pedersen 1999). Some workers have reported increased yield, fruit quality and leaf minerals content of apple using rice straw mulch (Bhutani et al 1994; Merwin \& Stiles 1994; Mika et al 1998 and Neilsen \& Hogue 1998). Chemical weed control in apple orchard became of great importance due to the high cost of farm labours at the present circumstances. Several investigator reported that application of Glyphosate gave excellent weed control in apple orchards and increasing leaf minerals content, yield and fruit quality (Akanda et al 1997; Cerda et al 1999 and Banaszkiewicz \& Kopytowski 2003).

This investigation tented to compare effectiveness of different weed control methods i.e., different colours of polyethylene mulch, rice straw mulch, herbicides and hand hoeing on weeds, leaf area, leaves mineral content, yield and fruit quality of Anna apple trees.

\section{MATERIALS AND METHODS}

The present study was performed during two successive seasons, 2005 and 2006 on four years old "Anna" apple trees (Malus domestica, Borkh), budded on Baladi apple (Indian crab) rootstock. Trees were spaced $4 \times 4 \mathrm{~m}$ apart grown in a private farm at El-Khatatba, Monofia governorate. All trees were almost uniform in vigor, grown in a sandy soil under conventionally accepted practices, using drip irrigation system. The soil mechanical and chemical properties are shown in Table (1). Thirty uniform trees were chosen randomly as 3 replicates (tree/replicate) in a randomized block design and grouped under ten treatments including unweeded.

Table 1. Mechanical and chemical analysis of the soil

\begin{tabular}{|cc|}
\hline Properties & Value \\
\hline Mechanical analysis: & \\
Sandy \% & 88.8 \\
Silt \% & 7.2 \\
Clay \% & 4.0 \\
Chemical analysis: & \\
pH (1:2.5 sus p.) & 8.63 \\
E.C. mmhos/cm ${ }^{3}$ & 0.16 \\
CaCo $\%$ & 2.8 \\
Organic matter \% & 0.51 \\
Available macroelements (meq/100g): \\
P & 1.8 \\
$\mathrm{~K}$ & 10.45 \\
$\mathrm{Ca}$ & 390 \\
$\mathrm{Mg}$ & 12.6 \\
$\mathrm{Na}$ & 20.24 \\
Available microelements (ppm) & \\
$\mathrm{Fe}$ & 2.0 \\
$\mathrm{Mn}$ & 3.1 \\
$\mathrm{Zn}$ & 0.2 \\
$\mathrm{Cu}$ & 0.3 \\
\hline
\end{tabular}

The experimental treatments as follows:

1. Unwedded.

2. Green plastic mulch.

3. Blue plastic mulch.

4. Red plastic mulch.

5. Black plastic mulch

6. Transparent plastic mulch.

7. Rice straw mulch

8. Hand hoeing (twice).

9. Glyfosinate (Basta): (2-amino-4-(hydroxylmethyl phosphinyl) butanoic acid) at 1.5L./200L. water/fed.

10. Glyphosate (Round up): (N-(phosphono methyl) glycine) at 2L./200L. water/fed.

In each season, rice straw mulch was setted in a layer of $15 \mathrm{~cm}$ in height in the $2^{\text {nd }}$ week in Feb- 
ruary around the tree trunk and covering the area under the tree canopy. Also, the different colours plastic mulch $(0.08 \mathrm{~mm}$ thick) were spread out on the soil surface as done with straw mulch. Hand hoeing treatment was carried out twice to control weeds at the end of both April and May at a depth of $10-15 \mathrm{~cm}$. Herbicides treatment were applied at the same time of hand hoeing.

Data were recorded during the two seasons of such study as follows

\section{I- The effect on weed control}

At harvest time, weed survey was conducted in one square meter from the middle part of each plot using hand-pulled and classified in to three classes

- Annual grasses.

- Annual broad-leaved weeds.

- Perennial weeds.

The fresh and dry weight of weeds at each class was determined as $\mathrm{g} / \mathrm{m}^{2}$.

\section{The effect on Anna apple}

Data of Anna apple trees include:

1- Leaf mineral content: samples of thirty leaves from the middle part of non fruited shoots were selected at random from each replicate to determinate both the leaf area and its mineral contents from macroelements $(\mathrm{N}$, $\mathrm{P}, \mathrm{K}, \mathrm{Mg}$ and $\mathrm{Ca}$ ) according to Evenhuis and De-Waard (1980) and microelements (Fe, $\mathrm{Mn}$ and $\mathrm{Zn}$ ) according to Jackson and Ulrich (1959).

2- Leaf area $\left(\mathbf{c m}^{2}\right)$ : leaf area was estimated at first of June by planimeter, according to Nauliyal et al (1990).

3- Yield (Kg) /tree: At harvesting time the yield was estimated on basis of number and weight of fruits/tree.

\section{4- Fruit characteristics}

Samples of 15 fruits from each tree were randomly taken for determining the physical and chemical characteristics:

\subsection{Physical characters}

Fruit weight $(\mathrm{g})$, fruit length $(\mathrm{L})$, fruit diameter (D) and L/D ratio were calculated. Also, fruit firmness was determined as Lb/inch ${ }^{2}$ by using fruit pressure tester mod. FT 327 (3-27Lbs).

\subsection{Chemical characters}

Total soluble solids percentage (TSS \%) was determined in fruit juice using a hand refractometer.

Total acidity (TA\%) was estimated as malic acid according to A.O.A.C. (1980).

\section{Statistical analysis}

The obtained data were subjected to proper statistical analysis of variance according to Snedecor and Cochran (1980). Means of treatments were compared using L.S.D. values at 0.05 level of significance.

\section{RESULTS AND DISCUSSION}

\section{Effect of weed control treatments on weeds}

The dominant weed species encountered in the experimental plots during the two seasons could be arranged as follows

a- Annual broad-leaved weeds: Malva parvillora L. (Small flowered mallon), Chenopodium album L. (White goosefoot), Amaranthus retroflexus L. (Pig weed red root) and Urtica urens L. (Small nettle).

b- Annual grasses weeds: Echinochloa colonum (L.) Link (deccan grass), Stedria viridis (L.) Beav (Green bristle grass) and Dinebra retroflexa (Forssk) Panz (tigergruss).

c- Perennial weeds: Cynodon dactylon (L) pers. Bermuda grass, Cyperus rotundus L. (nut grass) and Convolrulus arvensis L. (Lesser bind weed).

Fresh and dry weight of annual broad-leaved, annual grasses, perennial and total weeds in $\mathrm{g} / \mathrm{m}^{2}$ as affected by the tested weed control treatments (at harvesting) during both seasons were presented in Table (2). The obtained results indicated that different weed control methods revealed significant effects on fresh and dry weight of annual broad-leaved, annual grasses and perennial weeds in the two seasons of this study.

\section{I-1. Annual broad-leaved weeds}

Data recorded in Table (2) revealed that fresh and dry weight of annual broad-leaved weeds was significantly affected by different weed control treatments. 
Table 2. Fresh and dry weight of weeds at apple harvest as influenced by different weed control treatments (2005 and 2006 seasons).

\begin{tabular}{|c|c|c|c|c|c|c|c|c|c|c|c|c|c|c|c|c|}
\hline \multirow{3}{*}{ Treatments } & \multicolumn{8}{|c|}{ Fresh weight of weeds $\left(\mathrm{g} / \mathrm{m}^{2}\right)$} & \multicolumn{8}{|c|}{ Dry weight of weeds $\left(g / m^{2}\right)$} \\
\hline & \multicolumn{2}{|c|}{$\begin{array}{c}\text { Annual } \\
\text { broad leaved }\end{array}$} & \multicolumn{2}{|c|}{$\begin{array}{l}\text { Annual } \\
\text { grasses }\end{array}$} & \multicolumn{2}{|c|}{$\begin{array}{c}\text { Perennial } \\
\text { weeds }\end{array}$} & \multicolumn{2}{|c|}{$\begin{array}{l}\text { Total } \\
\text { weeds }\end{array}$} & \multicolumn{2}{|c|}{$\begin{array}{c}\text { Annual } \\
\text { broad leaved }\end{array}$} & \multicolumn{2}{|c|}{$\begin{array}{l}\text { Annual } \\
\text { grasses }\end{array}$} & \multicolumn{2}{|c|}{$\begin{array}{c}\text { Perennial } \\
\text { weeds }\end{array}$} & \multicolumn{2}{|c|}{$\begin{array}{l}\text { Total } \\
\text { weeds }\end{array}$} \\
\hline & 2005 & 2006 & 2005 & 2006 & 2005 & 2006 & 2005 & 2006 & 2005 & 2006 & 2005 & 2006 & 2005 & 2006 & 2005 & 2006 \\
\hline Unweeded (control) & 230 & 245 & 150 & 157.5 & 200 & 210 & 580 & 612.50 & 46.11 & 49.12 & 33.32 & 35.25 & 48.84 & 51.24 & 128.27 & 135.61 \\
\hline Green polyethylene mulch & $\mathbf{5 7 . 8 0}$ & 60.60 & 70 & 72.40 & 123 & 128.90 & 250.80 & 261.90 & 11.60 & 12.10 & 15.65 & 16.22 & 30.14 & 31.44 & 57.39 & 59.76 \\
\hline Blue polyethylene mulch & 39.51 & 41.32 & 54.63 & 57.14 & 13.62 & 14.21 & 107.76 & 112.67 & 7.91 & 8.26 & 12.11 & 12.71 & 3.32 & 3.55 & 23.34 & 24.52 \\
\hline Red polyethylene mulch & 97.50 & 101.41 & 101.52 & 105.60 & 60.53 & 62.92 & 259.55 & 269.93 & 19.52 & 30.34 & 22.62 & 23.64 & 14.84 & 15.33 & 56.98 & 59.31 \\
\hline Black polyethylene mulch & 0.52 & 0.66 & 0.49 & 0.62 & 1.72 & 1.83 & 2.73 & 3.11 & 0.10 & 0.13 & 0.10 & 0.14 & 0.42 & 0.45 & 0.62 & 0.72 \\
\hline $\begin{array}{l}\text { Transparent polyethylene } \\
\text { mulch }\end{array}$ & 190.51 & 2.00 & 130 & 136.56 & 161 & 169.12 & 481.51 & 505.68 & 38.12 & 40 & 28.92 & 30.51 & 39.32 & 41.24 & 106.36 & 111.75 \\
\hline Rice straw mulch & 0.0 & 0.0 & 0.0 & 0.0 & 0.0 & 0.0 & 0.0 & 0.0 & 0.0 & 0.0 & 0.0 & 0.0 & 0.0 & 0.0 & 0.0 & 0.0 \\
\hline Two hand hoeing & 11.50 & 12.40 & 18.25 & 21.17 & 19.52 & 21.34 & 49.27 & 54.91 & 2.41 & 2.52 & 4.05 & 4.70 & 4.90 & 5.20 & 11.36 & 12.42 \\
\hline Glyfosinate herbicide & 7.00 & 7.86 & 11.11 & 13.31 & 25.21 & 26.91 & 43.32 & 48.08 & 1.52 & 1.62 & 2.47 & 2.96 & 6.00 & 6.64 & 9.99 & 11.22 \\
\hline Glyphosate herbicide & 10.22 & 13.42 & 8.23 & 11.52 & 0.00 & 0.00 & 18.45 & 24.94 & 2.21 & 2.87 & 1.84 & 2.60 & 0.00 & 0.00 & 4.05 & 5.47 \\
\hline L.S.D.0.05 & 23.53 & 24.62 & 15.22 & 17.23 & 18.71 & 19.24 & 35.11 & 39.17 & 1.12 & 1.19 & 1.03 & 1.11 & 2.13 & 2.07 & 4.32 & 4.22 \\
\hline
\end{tabular}

Rice straw mulching treatment gave the best control when compared with the other treatments in both 2005 and 2006 seasons. It reduced fresh and dry weight of annual broad-leaved weeds than unwedded check by $100 \%$ reduction in both seasons. Treatments of black polyethylene, Glyfosinate, Gluphosate and two hand hoeing were very effective in controlling most annual broad-leaved weeds recorded. On the contrary, the highest fresh and dry weight of annual broadleaved weeds were observed with unweeded followed by that of transparent polyethylene mulch and red polyethylene mulch treatments. These results could be due to the inhibition effect of rice straw mulch, black polyethylene mulch and herbicidal treatments on growth of weeds.

\section{I.2. Annual grasses}

Fresh and dry weight of annual grasses weeds as affected by different weed control treatments are presented in Table (2). It is obvious that weed control treatments revealed significant influence on fresh and dry weight of grassy weeds. Rice straw mulch treatment was more effective in controlling the annual grassy weeds spread in the tested apple orchard (100\% reduction) followed by that of black polyethylene, Glyphosate, Glyfosimate herbicides and two hand hoeing treatments, respectively. These results may be due to the inhibition and deleterious effect of weed control treatments on growth of weeds. Mulching of rice or black polyethylene were the most effective on 
controlling apple weeds. This may be due to attributable efficiency of mulching in stunting of weeds. On the other hand, the unweeded treatment resulted the highest values of fresh and dry weight of weeds in both seasons.

\section{I.3. Perennial weeds}

Relevant data show that fresh and dry weight of perennial weeds at harvesting were significantly decreased by different weed control treatments when compared with unweeded check in both seasons (Table 2). Rice straw mulch treatment followed by Glyphosate, black polyethylene, two hand hoeing and Glyfosinate were very effective in controlling most perennial weeds. These superior treatments decrease the average of fresh weight of perennial weeds than unweeded treatment by about 100, 100, 99.14, 90.24 and $87.40 \%$, in the first season and by $100,100,99.13,89.84$ and $87.19 \%$, in the second season, respectively. However, the maximum values of fresh and dry weight of perennial weeds were observed with unweeded treatment followed by that of transparent, red and green polyethylene mulch in both seasons as shown in Table (2). These results may be due to mulching smothering effect on weeds by excluding light from the photosynthetic portions of a plant which inhibiting the vegetative growth for such weeds. It is very effective against annual and some perennial weeds (Radwan and Hussein 2001).

\section{I.4. Total weeds}

The available results in Table (2) indicated that weed control treatments have a significant influence on fresh and dry weight of total weeds during both seasons. The highest reduction effect in fresh and dry weight was significantly obtained with rice straw mulch treatment followed by black polyethylene. The reduction percentage in fresh weight reached 100, 99.53, 96.82, 92.53 and 91.51 in the first season, and 100, 99.49, 95.93, 92.15 and $91.04 \%$, in the second season for rice straw mulch, black polyethylene, Glyphosate, Glyfosinate and two hand hoeing treatments, respectively. In contrast, the maximum value of fresh and dry weight of total weeds were recorded by unweeded treatment.

Results concerning effect of mulching with rice straw or black polyethylene, may be due to reducing penetrability of light necessary for weed photosynthesis results in restriction of growth, wilting and death. The results of rice straw mulching are in agreement with the finding of Hartley \& Rahman (1997) Mika et al (1998); Pedersen (1999) and Abou Sayed et al (2005) who found that rice straw mulching gave complete control of annual weeds and the majority of prevailing perennial weeds as compared with the control. While, Cerda et al (1999) and Banaszkiewicz \& Kopytowski (2003) reported that application of Glyphosate herbicide significantly decreased weed density and dry weight of annual grasses, annual broad-leaved, perennial and total weeds spread in apple orchard when compared with unweeded treatment.

Generally, results in Table (2) showed that all weed control treatments statistically decreased fresh and dry weight of total weeds grown with apple as compared to unweeded treatment. Rice straw mulch, black polyethylene, Glyphosate, Glyfosinate and two hand hoeing were the most effective for controlling of apple weeds. Similar conclusion was mentioned by Bhutani et al (1994); Akanda et al (1997); Pedersen (1999) and Abou Sayed et al (2005). However, there were no significant differences among mulching (rice straw and black polyethylene), herbicidal (Glyphosate and Glyfosinate) and two hand hoeing treatments, in fresh and dry weight of annual broad-leaved, annual grasses, perennial and total weeds.

\section{Effect of weed control treatments on apple trees}

\section{II.1. Leaf area $\left(\mathrm{cm}^{2}\right)$ and leaf mineral content affected by the different weed control treatments}

Data recorded in Table (3) show that leaf area was significantly increased as a result of controlling weeds by different weed control treatments as compared to the unweeded treatment, in both seasons. The maximum value of leaf area was recorded by rice straw mulching followed by that of black polyethylene mulch and Glyphosate treatments, in both seasons. On the other hand, the lowest value of leaf area was recorded in the unweeded check. Application of the previous treatments was effective in controlling weeds and consequently the competition limites of light, water and nutrients available for promote apple trees when compared with other treatments. 
Results in Table (3) revealed that all weed control treatments significantly increased leaf

mineral content. The highest values of $\mathrm{N} \%, \mathrm{P} \%$, 
Table 3. Leaf area $\left(\mathrm{cm}^{2}\right)$ and leaf mineral content of Anna apple as influenced by different weed control treatments (2005\& 2006 seasons).

\begin{tabular}{|c|c|c|c|c|c|c|c|c|c|c|c|c|c|c|c|c|c|c|c|c|}
\hline \multirow[t]{2}{*}{ Treatments } & \multicolumn{2}{|c|}{$\begin{array}{c}\text { Leaf area } \\
\qquad\left(\mathrm{cm}^{2}\right)\end{array}$} & \multicolumn{2}{|c|}{$\begin{array}{l}\mathbf{N} \\
\%\end{array}$} & \multicolumn{2}{|c|}{$\begin{array}{l}\mathbf{P} \\
\%\end{array}$} & \multicolumn{2}{|c|}{$\begin{array}{l}\mathbf{K} \\
\%\end{array}$} & \multicolumn{2}{|c|}{$\begin{array}{l}\mathrm{Ca} \\
\%\end{array}$} & \multicolumn{2}{|c|}{$\begin{array}{c}\mathrm{Mg} \\
\%\end{array}$} & \multicolumn{2}{|c|}{$\begin{array}{c}\mathrm{Fe} \\
\mathrm{ppm}\end{array}$} & \multicolumn{2}{|c|}{$\begin{array}{c}\mathrm{Zn} \\
\mathrm{ppm}\end{array}$} & \multicolumn{2}{|c|}{$\begin{array}{l}\text { Mn } \\
\text { ppm }\end{array}$} & \multicolumn{2}{|c|}{$\begin{array}{c}\mathrm{Cu} \\
\mathrm{ppm}\end{array}$} \\
\hline & 2005 & 2006 & 2005 & 2006 & 2005 & 2006 & 2005 & 2006 & 2005 & 2006 & 2005 & 2006 & 2005 & 2006 & 2005 & 2006 & 2005 & 2006 & 2005 & 2006 \\
\hline Unweeded & 22.30 & 21.61 & 1.44 & 1.48 & 0.114 & 0.107 & 1.29 & 1.38 & 0.60 & 0.67 & 0.36 & 0.30 & 133 & 156 & 30.42 & 28.51 & 60.13 & 57.38 & 5.44 & 5.23 \\
\hline $\begin{array}{l}\text { Green polyeth- } \\
\text { ylene mulch }\end{array}$ & 24.79 & 24.41 & 1.59 & 1.71 & 0.125 & 0.120 & 1.56 & 1.56 & 0.77 & 0.79 & 0.50 & 0.42 & 144.5 & 166.5 & 38.59 & 35.62 & 68.53 & 66.43 & 6.75 & 6.20 \\
\hline $\begin{array}{l}\text { Blue polyeth- } \\
\text { ylene mulch }\end{array}$ & 25.01 & 24.86 & 1.63 & 1.76 & 0.138 & 0.125 & 1.66 & 1.61 & 0.82 & 0.79 & 0.52 & 0.48 & 158 & 174 & 38.32 & 37.57 & 70.42 & 67.12 & 7.00 & 7.14 \\
\hline $\begin{array}{l}\text { Red polyeth- } \\
\text { ylene mulch }\end{array}$ & 23.60 & 23.03 & 1.47 & 1.67 & 0.124 & 0.119 & 1.47 & 1.52 & 0.74 & 0.77 & 0.48 & 0.40 & 139 & 157.5 & 38.53 & 34.30 & 65.50 & 64.00 & 6.31 & 6.82 \\
\hline $\begin{array}{l}\text { Black polyeth- } \\
\text { ylene mulch }\end{array}$ & 26.06 & 26.79 & 1.93 & 1.95 & 0.157 & 0.145 & 2.00 & 1.85 & 0.91 & 0.86 & 0.63 & 0.55 & 207 & 195.5 & 50.17 & 41.66 & 81.73 & 76.21 & 7.50 & 7.93 \\
\hline $\begin{array}{l}\text { Transparent } \\
\text { polyethylene } \\
\text { mulch }\end{array}$ & 23.15 & 22.88 & 1.46 & 1.55 & 0.118 & 0.110 & 1.38 & 1.45 & 0.67 & 0.74 & 0.46 & 0.39 & 142 & 137 & 36.64 & 29.86 & 65.17 & 60.25 & 5.97 & 5.90 \\
\hline $\begin{array}{l}\text { Rice straw } \\
\text { mulch }\end{array}$ & 26.78 & 27.35 & 2.00 & 2.07 & 0.168 & 0.154 & 2.03 & 1.90 & 0.98 & 0.91 & 0.66 & 0.55 & 221 & 203 & 53.12 & 48.11 & 84.12 & 79.51 & 8.10 & 8.41 \\
\hline $\begin{array}{l}\text { Two hand } \\
\text { hoeing }\end{array}$ & 25.17 & 24.92 & 1.68 & 1.84 & 0.153 & 0.131 & 1.87 & 1.61 & 0.84 & 0.82 & 0.54 & 0.48 & 172.5 & 179.5 & 40.81 & 39.22 & 74.12 & 71.00 & 7.00 & 7.52 \\
\hline $\begin{array}{l}\text { Glyfosinate } \\
\text { herbicide }\end{array}$ & 25.51 & 25.07 & 2.07 & 2.18 & 0.168 & 0.162 & 2.10 & 1.96 & 0.86 & 0.84 & 0.55 & 0.49 & 183 & 192.5 & 40.52 & 40.10 & 75.17 & 71.18 & 8.73 & 8.63 \\
\hline $\begin{array}{l}\text { Glyphosate } \\
\text { herbicide }\end{array}$ & 25.83 & 25.28 & 2.19 & 2.25 & 0.174 & 0.185 & 2.27 & 2.02 & 0.89 & 0.86 & 0.57 & 0.53 & 191.5 & 193 & 41.11 & 40.51 & 77.42 & 73.53 & 8.91 & 9.21 \\
\hline L.S.D. 0.05 & 0.94 & 0.88 & 0.23 & 0.29 & 0.112 & 0.103 & 0.19 & 0.16 & 0.09 & 0.07 & 0.13 & 0.10 & 17 & 19 & 4.12 & 3.96 & 5.43 & 4.54 & 0.42 & 0.51 \\
\hline
\end{tabular}

$\mathrm{K} \%, \mathrm{Zn}(\mathrm{ppm})$ and $\mathrm{Cu}(\mathrm{ppm})$ in apple leaves were obtained by Glyphosate, Glyfosinate, rice straw mulch, black polyethylene mulch and two hand hoeing treatments, respectively. While, application of rice straw mulch, black polyethylene mulch, Glyphosate, Glyfosinate and two hand hoeing treatments consecutively recorded the highest $\mathrm{Ca} \%, \mathrm{Mg} \%, \mathrm{Fe}$ (ppm) and $\mathrm{Mn}$ (ppm) in apple leaves compared to the other weed control treatments in both seasons. The lowest value of all the aforementioned characters was obtained when apple orchards were unweeded. These results may be due to the less competition for nutrients, water and light through limiting weeds infestation with mulching (rice straw and black polyethylene) and herbicides (Glyphosate and Glyfosinate) as well as two hand hoeing treatments due to increasing the uptake of different nutrients. The results are in harmony with those obtained by Merwin and Stiles (1994); Merwin et al (1995); Neilsen and Hogue (1998) and Pedersen (1999).

\section{II.2. Fruit physical and chemical characteristics and yield of Anna apple}

\section{II.2.1. Physical Characters}

Results in Table (4) indicated that fruit weight $(\mathrm{g})$, fruit length $(\mathrm{cm})$, fruit diameter $(\mathrm{cm})$, fruit 
Table 4. Yield and fruit physical and chemical characteristics of Anna apple as influenced by different weed control treatments (2005 \& 2006 seasons).

\begin{tabular}{|c|c|c|c|c|c|c|c|c|c|c|c|c|c|c|c|c|c|c|}
\hline \multirow[t]{2}{*}{ Treatments } & \multicolumn{2}{|c|}{$\begin{array}{l}\text { Average fruit } \\
\text { weight }(\mathrm{g})\end{array}$} & \multicolumn{2}{|c|}{$\begin{array}{l}\text { Number of } \\
\text { fruits/tree }\end{array}$} & \multicolumn{2}{|c|}{$\begin{array}{l}\text { Yield/tree } \\
(\mathrm{Kg})\end{array}$} & \multicolumn{2}{|c|}{$\begin{array}{c}\text { Fruit length } \\
(\mathrm{cm})\end{array}$} & \multicolumn{2}{|c|}{$\begin{array}{l}\text { Fruit diameter } \\
\qquad(\mathrm{cm})\end{array}$} & \multicolumn{2}{|c|}{$\begin{array}{l}\mathrm{L} / \mathrm{D} \\
\text { ratio }\end{array}$} & \multicolumn{2}{|c|}{$\begin{array}{c}\text { Fruit firmness } \\
\left(\mathrm{Lb} / \mathrm{inch}^{2}\right)\end{array}$} & \multicolumn{2}{|c|}{$\begin{array}{l}\text { TSS } \\
(\%)\end{array}$} & \multicolumn{2}{|c|}{$\begin{array}{l}\mathrm{TA} \\
(\%)\end{array}$} \\
\hline & 2005 & 2006 & 2005 & 2006 & 2005 & 2006 & 2005 & 2006 & 2005 & 2006 & 2005 & 2006 & 2005 & 2006 & 2005 & 2006 & 2005 & 2006 \\
\hline Green polyethylene mulch & 173.24 & 160.23 & 138.4 & 129.1 & 23.98 & 20.68 & 7.23 & 7.30 & 6.53 & 6.70 & 1.11 & 1.10 & 11.11 & 11.26 & 12.22 & 12.41 & 0.57 & 0.51 \\
\hline Blue polyethylene mulch & 175.18 & 161.62 & 146.1 & 133.3 & 25.59 & 21.55 & 7.27 & 7.37 & 6.67 & 6.73 & 1.10 & 1.10 & 11.43 & 11.60 & 12.27 & 12.53 & 0.60 & 0.58 \\
\hline $\begin{array}{l}\text { Transparent polyethylene } \\
\text { mulch }\end{array}$ & 150.50 & 136.13 & 111.9 & 111.0 & 16.84 & 15.11 & 6.50 & 7.07 & 6.33 & 6.07 & 1.03 & 1.16 & 10.24 & 10.4 & 11.59 & 10.90 & 0.49 & 0.45 \\
\hline Rice straw mulch & 210.90 & 198.74 & 156.8 & 143.2 & 33.07 & 28.46 & 8.23 & 8.20 & 7.30 & 7.13 & 1.13 & 1.15 & 13.31 & 13.4 & 13.60 & 13.53 & 0.43 & 0.45 \\
\hline Two hand hoeing & 215.24 & 200.43 & 126.1 & 116.2 & 27.15 & 23.25 & 7.37 & 7.43 & 6.77 & 6.90 & 1.10 & 1.10 & 13.53 & 13.80 & 13.20 & 13.87 & 0.40 & 0.45 \\
\hline Glyfosinate herbicide & 183.11 & 173.18 & 145.7 & 132.5 & 26.68 & 22.94 & 7.53 & 7.47 & 6.80 & 6.73 & 1.11 & 1.11 & 11.92 & 12.0 & 12.85 & 12.82 & 0.62 & 0.68 \\
\hline
\end{tabular}

firmness $\left(\mathrm{Lb} / \mathrm{inch}^{2}\right)$, $\mathrm{L} / \mathrm{D}$ ratio and number of fruits/tree were significantly increased by using weed control treatments. This was true for both experimental seasons. Rice straw mulching treatment recorded the highest values of fruit length, fruit diameter, L/D ratio and number of fruits/tree followed by that of black polyethylene, Glyphosate, Glyfosinate and two hand hoeing treatments. Meanwhile, the highest values of fruit weight and fruit firmness were recorded by two hand hoeing, rice straw mulch, black polyethylene mulch, Gluphosate and Glufosinate treatments. On the contrary, the lowest values of all the aforementioned characters were recorded with the unweeded treatment. The increase in major characters of fruits by different weed control treatments may be due to good control of apple weeds and minimized weed competition which gave good chance for apple trees growth and improved growth characters and fruit quality. These results are in harmony with the findings of Mika et al (1998); Neilsen \& Hogue (1998) and Pedersen (1999).

\section{II.2.2. Yield (kg)/tree}

In both seasons, weed control treatments developed significant effects on yield $(\mathrm{kg}) /$ tree of apple trees as shown in Table (4). Mulching, both herbicides and two hand hoeing treatments markedly produced higher yield $(\mathrm{kg})$ /tree than unweeded plots. Rice straw and black polyethylene mulching, Glyphosate, two hand hoeing and Glyfosinate treatments recorded the greatest yield/tree as compared with the other treatments. These superior treatments increased the average of yield $(\mathrm{kg}) /$ tree than unweeded treatment by about $110.0,92.9,83.5,72.4$ and $69.4 \%$ in the first season and 91.8, 88.2, 65.3, 56.7 and $54.6 \%$ in the second season, respectively. In contrast the lowest value of yield/tree was recorded with the unweed- 
ed plots ( 15.75 and $14.84 \mathrm{~kg} /$ tree) consecutively in the both seasons.

The previous mentioned enhancement on growth and nutritional status of the trees surely reflected an improving tree productivity. The results obtained here indicate that rice straw mulch, black polyethylene, Glyphosate herbicide and two hand hoeing produced a promising effect against weeds prevailing on apple growth, nutritional status of the trees, yield $(\mathrm{kg}) /$ tree and main characteristics comparison with the other treatments. The superiority in tree productivity may be due to accumulative effect of weed control treatments that resulted in better eradication, otherwise liminated dangerous competitive weeds. These results are in agreement with those reported by Hassan (2001); Abou Sayed et al (2005) and Hassan et al (2006) observed that the rice straw mulching treatment gave the highest yield/tree when compared with all herbicides treatments. On the other hand, Merwin et al (1995) and Falta et al (2002) who reported that Glyphosate treatment gave the maximum value of yield/tree compared with other treatments.

\section{II.2.3. Fruit chemical properties}

As show in Table (4) all tested weed control treatments significantly improved fruit quality that enhanced total soluble solids \% (TSS\%) and depressed total acidity \% (TA\%) in fruit juice of Anna apple, in both 2005 \& 2006 seasons.

Concerning the TSS\% of these treatments ranged 11.59 to $13.6 \%$ in the $1^{\text {st }}$ season and 10.9 to $13.87 \%$ in the $2^{\text {nd }}$ season. The best $\mathrm{TSS} \%$ results were obtained from rice straw mulch, black polyethylene mulch and two hand hoeing treatments, followed by the herbicide treatments. The lowest statistical values of TSS\% received by the unweed treatment, recorded $11.53 \& 10.73 \%$ respectively in both seasons. The other tested treatments revealed intermediate values.

Regarding to the effect of these treatments on (TA\%), data presented in Table (4) show clearly that all treatments decreased TA\% in apple fruit juice than the unweeded trees. Moreover, the best treatments showed nearly similar trend as shown for TSS\%. Mean while, the herbicides treatments indicated insignificant differences considering the control treatment. These record showed the highest significant values of TA\% when compared with the other treatments. These results were true in 2005 and 2006 seasons.

As a conclusion from the obtained results in this study, rice straw mulch, black polyethylene mulch and hand hoeing twice treatments developed the best and good recommendation for weed control in apple orchard. Moreover, improving growth, leaves mineral content, and yield (kg/tree), as well as enhancing the physical and chemical properties of apple fruits.

\section{REFERENCES}

A.O.A.C. (1980). Official Methods of Analysis $\mathbf{1 3}^{\text {th }}$ Ed. Associations of Official Agricultural Chemists, Washington. D.C., U.S.A.

Abou Sayed, A.T. A.; R.A. Al-Ashkar; L.A. ElMashad and A.R. Bdr El-Deen (2005). Comparative study of some integrated weed control treatments on Washington Navel Orange trees and associated weeds. Zagazig J. Agric. Res., 32(1): 35-56.

Akanda, R.U.; J.J. Mullahey; C.C. Dowler and D.G. Shilling (1997). Influence of post-emergence herbicides on tropical soda apple and bahiagrass. Weed Tech., 11(4): 656-661.

Banaszkiewicz, T. and J. Kopytowski (2003). Some aspects of glyphosate use in apple orchards. Sodininkyste-ir-Darzininkyste, 22(1): 41-46.

Bhutani, V.P.; S.S. Raina; U.U. Khokar (1994). Effect of herbicides, mulching and clean cultivation on weed population growth and cropping of apple trees. Horticultural J., 7(1): 7-13.

Cerda, J.J.; M. Mendoza; J. Santiago; F. Nieto and S. Cortez (1999). Weed chemical control in apple (Pyrus malus L.): Coadjuvants. Agronomia Mesoamericana, 10(1): 7-15.

El-Shamma, M.S. and A.A.A. Hassan (2001). A comparative study of some weed control methods on Thompson seedless vines. Assiut J. Agric. Sci., 32(1): 145-155.

Evenhuis, B. and W. De-Waard (1980). Principales and practices in plant analysis. F.A.O. Soil Bull., 38: 152-163.

Falta, V.; M. Prazak and M. Hudsky (2002). Elimination of weed influence through fruit thinning and fertilization in apple tree plantings. Zahradnictri. Horticultural Science, 29(4): 143-147. Hartley, M.J. and A. Rahman (1997). Organic mulches for weed control in apple orchards. Orchardist, 70(10): 28-30.

Hassan, A.A.A. (2001). A comparative study of some weed control treatments on Washington Navel orange orchard. J. Agric. Sci. Mansoura Univ., 26(3): 1381.

Hassan, A.A.A.; T.A. El-Shahawy and G.M. Metwely (2006). Annual and perennial weed con- 
trol in citrus orchard. Bull. NRC, Egypt, 31(1): 77-86.

Hussein, H.F. and S.M.A. Radwan (2002). Bioorganic fertilization of potato under plastic mulches in relation to quality of production and associated weeds. Arab Univ. J. Agric. Sci., Ain Shams Univ., Cairo, 10(1): 287-309.

Jackson, M.L. and A. Ulrich (1959). Analytical methods for use in plant analysis. Coll. Agric. Exp. State Bull., 766: 35.

Merwin, I.A. and W.C. Stiles (1994). Orchard ground cover management impacts on apples tree growth and yield and nutrient availability and uptake. J. Amer. Soc. Hort. Sci., 119(2): 209-215.

Merwin, I.A.; D.A. Rosenberger; C.A. Engle; D.L. Rist and M. Fargione (1995). Comparing mulches, herbicides and cultivation as orchard ground cover management systems. Hort. Tech., 5(2): 151-158.

Mika, A.; D. Krzewinska and T. Olszewski (1998). Effects of mulches, herbicides and cultivation as orchard ground cover management system in young apple orchard. J. of Fruit and Ornamental Plant Research, 6(1): 1-13.

Nauliyal, M.C.; P.K. Singh; R.N. Shukla; S. Parkash and M. Kummar (1990). Correcting leaf area measurement by conventional methods: a new approach for apple (Malus domestica Borkh). J. Hort. Sci., 65: 15-18.

Neilsen, G.H. and E.J. Hogue (1998). Mulches and composted organic wastes as components of integrated fruit production. Ecological aspects of nutrition and alternatives for herbicides in Horticulture. Proc. International Seminar, Warszawa. Poland, pp. 55-56.

Pedersen, H.L. (1999). Alternatives to herbicide use fo controlling weeds in apple orchards. Rivista-di-frutticoltura-e-di-Ortofloricoltura, 61(10):81-83.

Radwan, S.M.A. and H.F. Hussein (2001). Response of onion (Allium cepa, L.) plants and associated weeds to biofertilization under some plant mulches. Annals. Agric. Sci. Ain Shams Univ., Cairo, 46(2): 543-564.

Sabbah, S.M.; Aida, T.Assal and Elham, A. Ghaly (1994). The relative influence of some herbicides on yield, fruit quality and leaf mineral composition of Washington Navel Orang trees. Annals Agric. Sci., Ain Shams Univ., Cairo, 39(2): 721-729.

Sinbel, H.M.; Aida, S. Assal and El-ham, A. Ghaly (1997). A comparative study of weed control method. Effect on growth, yield and fruit quality of Washington Navel orange trees. J. Agric. Sci. Mansoura Univ. 22(7): 2403-2411.

Snedecor, G.W. and W.G. Cochran (1980). Statistical Method $7^{\text {th }}$ Ed. p. 507. Iowa State Univ. Press., Ames, Iowa, U.S.A.

Stino, G.R.; M.M. Zaki and A. Abd El-Aziz (1985). Introduction of low chilling apple cultivars in Egypt. Tech. Bulletin 4/1985, Ministry of Agriculture, Cairo A.R.E. 